Piotr Lesiak

Dr hab. inż.

Wyższa Szkoła Ekonomii i Innowacji w Lublinie

Wydział Transportu i Informatyki

piotr.lesiak@wsei.lublin.pl

DOI: 10.35117/A_ENG_21_09_01

\title{
Drones in visual diagnostics of defects in railway rails
}

\begin{abstract}
The paper discusses the possibilities of the use of drones in the visual diagnostics of the railway track. Examples of extensive defects in the railhead are shown, along with methods of image processing and analysis. Pros and cons of such a research were presented. Suggested directions for their implementation at PKP PLK S.A. were presented.
\end{abstract}

Keywords: Drones; Railway rails; Vision research; Safety

\section{Introduction}

An increasing number of managers of the world's rail networks are striving to create an innovative "digital rail", that is, an accurate and dynamic system used, inter alia, to identify actual and potential damage to the railway infrastructure. This is based on obtaining the highest quality data, thanks to which decisions are made during planning and prioritization in the field of development, maintenance, repair and renovation of railways are supported [8].

Drones, which can control significant sections of railway lines in real time, have become a tool supporting these tasks with great success. They are also called UAV - Unmanned Aerial Vehicle. They can perform visual inspections of railway infrastructure within sight, VLOS Visual Line of Sight, or out of sight (control via the image transmitted from the drone), BVLOS - Beyond Visual Line of Sight [[24]].

There are drones available on the market that allow for mounting the highest-quality imaging equipment and various sensors, which allow recording data not only about functional values but also to conduct scientific research quality work. In addition to vision cameras, also standard are multispectral cameras, thermovision, temperature sensors, laser, gas, etc. [22].

The measurement is made with an accuracy of fractions to single millimeters. Once captured, overlapping aerial images are processed in photogrammetry software to produce an accurate $3 \mathrm{D}$ point cloud. By comparing with reference point clouds from previous inspections, you can monitor infrastructure changes.

Thanks to the reference drone-based railway surveillance architecture, it is possible to quickly detect damage and prevent accidents, Fig. 1. It also significantly reduces the workforce input, introduces savings in research costs and time, and provides immediate access to data.

When considering the usefulness of drones as tools useful on the railroad, it is necessary to take into account the practical technical possibilities in individual groups of applications, from the simplest such as intrusion monitoring, deterring intruders (thieves), vandalism - the PKP Cargo project [5], through more sophisticated ones, such as include: monitoring and inspection of infrastructure such as bridges and viaducts (detection of defects such as losses, cracks, deformations, corrosion of structures and intelligent maintenance) [7], [14], [16], tunnels (gauge) [18], [26], faults of devices control of railway traffic [9], [24], and the surface of tram and railway lines (deformations and surface defects of rails, cracks in sleepers, control of heating of turnouts, maintenance of switches, defects in the track structure, vegetation) [1], [6], [ 15], [20], [21], [23], as well as damage to railway traction (poles and lattice structures, insulators, cables, transformer stations), railway buildings (technical condition, energy 
efficiency, construction disasters), mapping railway investments (high resolution geodetic images) - 2018 agreement between PKP PLK SA and Fotoraporty Sp. z o.o.

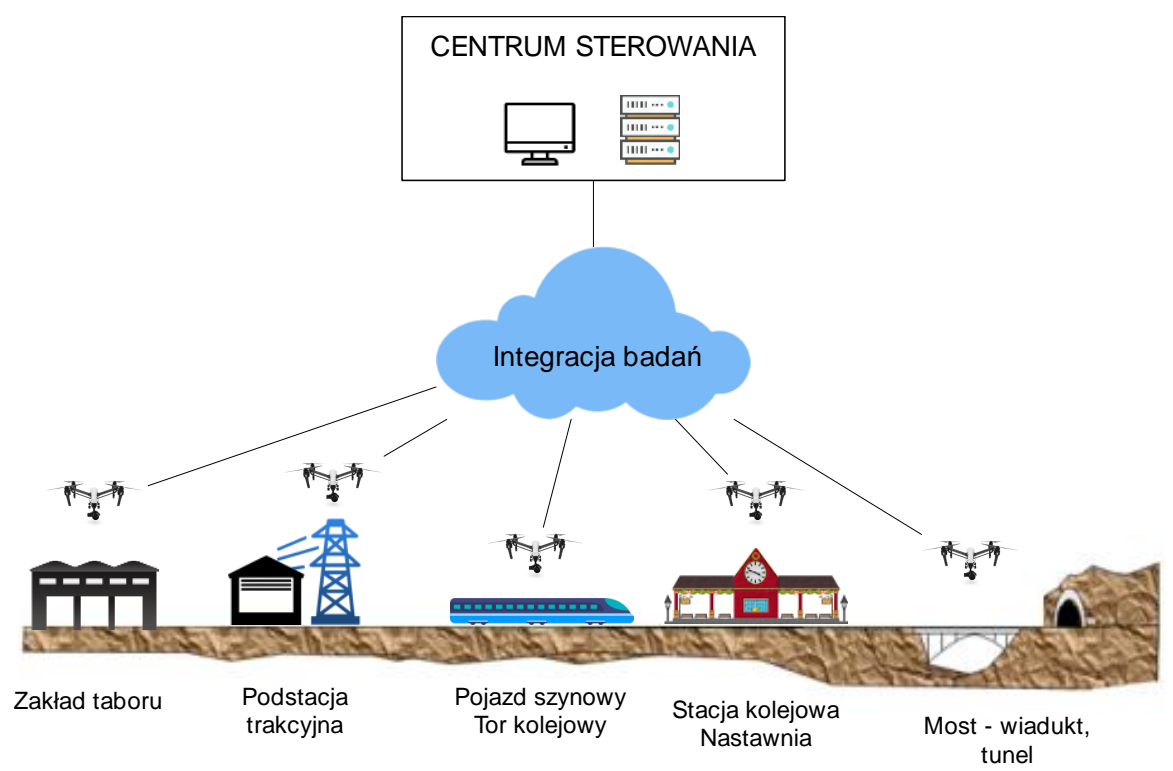

1. Reference architecture for the supervision of railway infrastructure based on drones [[6], [22]]

It should be emphasized that the drone market in the last decade has grown exponentially on a global scale, and in 2019 it amounted to approximately $\$ 4$ billion in rail applications [[8]].

Therefore, the article focuses on the use of drones to support the inspection of the railway infrastructure, with particular emphasis on vision systems for processing defects in rails.

The global review of the use of drones in the inspection of railway infrastructure and innovative systems for the use of autonomous drones in this area was the subject of the author's considerations in the work [[13]].

\section{Video surveys of the railway track with drones}

As standard, professional drones are equipped with devices that enable taking extremely precise aerial photos, using Ultra 4K cameras with an image resolution of $100 \mathrm{MPx}$, with the function of video recording in UHD - Ultra High Definition with a resolution of $4096 \times 2160$, with various frame rates and with a variable system of vision - vertically downwards or horizontally, depending on the tested objects. For example, the Visual system Intelligence LLC [25] can survey the track area of $15 \times 11$ meters from a height of $21 \mathrm{~m}$, with $90 \%$ overlap, while maintaining a speed of $5 \mathrm{~m} / \mathrm{s}$, which translates into a capture speed of 4 frames per second. With such a high resolution, it is possible to identify defects in the running surface of the rail head [23], markings on sleepers, the quality of installation of rail fastenings and joints, or damage to the structure and surfaces of viaducts and bridges. It is a key function in the inspection of railway tracks, with the accompanying infrastructure, Figure 2.

The conceptual solution is a hybrid drone, delivered by train to the research site. Initially, it is docked at the end of a moving train (then it has recharged batteries) and is heading to the suspicious location of the damaged track, Fig. 3.

With the help of GPS, the drone can take off when the train is approaching the target area and then moves at a specific height along the track, visually recording areas with visible rail surface defects, missing rail fastening tabs, or broken sleepers. If necessary, the drone can land on the rail and perform a more detailed inspection of the rail while driving along the rail 
using 3D reconstruction. After the tests, the UAS will take off again and land near the track waiting for the next train to dock Fig. 3. This hybrid drone has the ability to fly and land on 1$2 \mathrm{~km}$ of the track section at a speed of 5-10 m/s [18] and [[26]].

a)

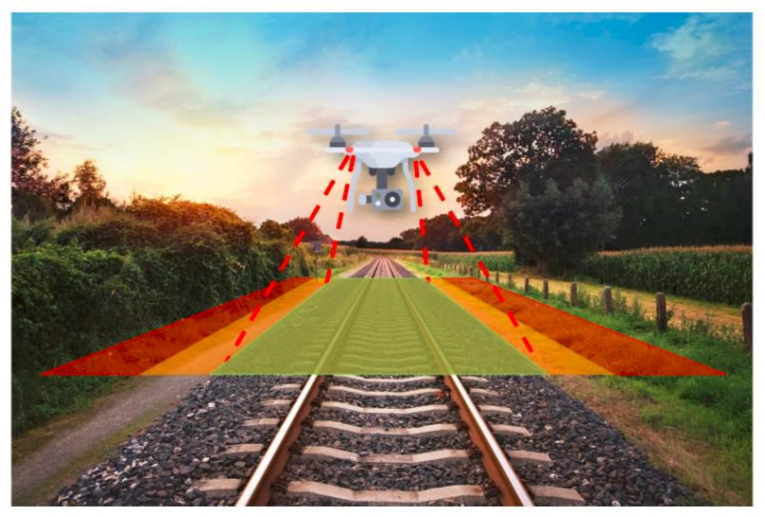

c)

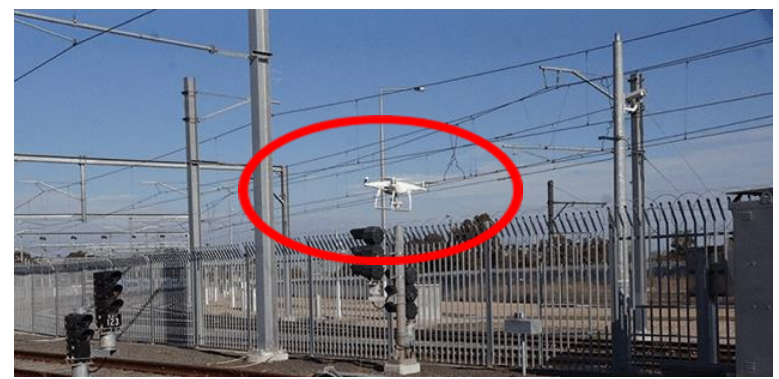

b)

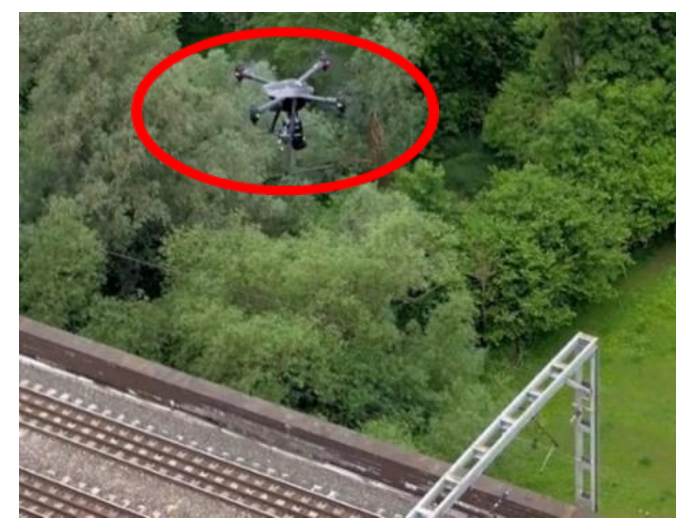

d)



2. Video scanning of the railway track with a drone: a) illustrative illustration of the test [15], b) the actual test [4] and c) [2], d) high-resolution view of the substructure (subtitles) [[4]], [[17]]

a)

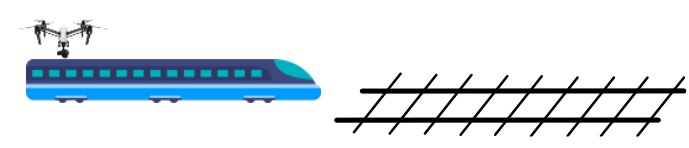

c)

Przemieszczanie się drona wzdłuż szyny

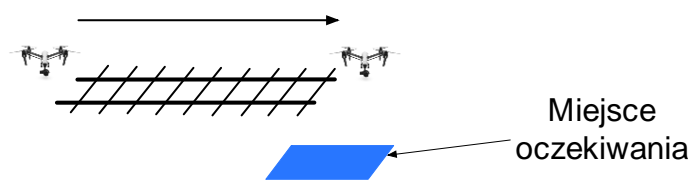

b) Kontrola wizyjna toru

d)
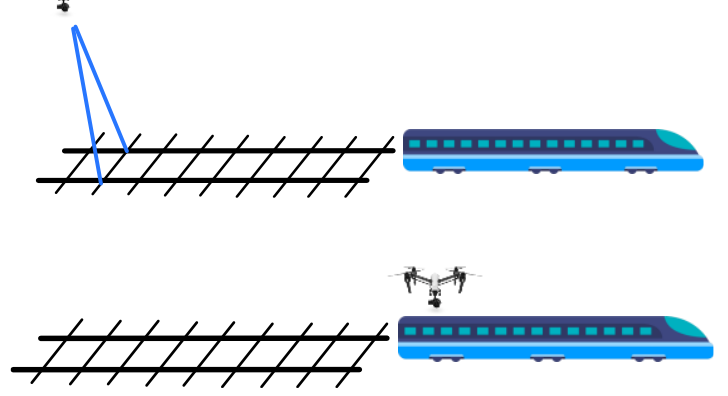

3. Hybrid UAS scenario [26]: a) transport of the drone by train to the research area, b) visual inspection of the track, c) direct testing of rails and waiting for the next train, d) departure by another train

\section{Algorithm for processing images of defects in rails}

The effectiveness of visual diagnostics of rails with the use of drones requires the development of an algorithm for image processing and analysis. During the tests, the drone should be significantly resistant to changing environmental conditions, which is to be ensured by its onboard systems. Therefore, its dynamics and broadly understood flight stability at the same 
optimal altitude are important here. Vibrations should be eliminated to a minimum, as they may lead to blurry photos [3]. The high quality of the optics is also important here, as well as the high accuracy of the location of the drone, which is to be ensured by the GPS system.

As the object of the experimental research, tracks were selected from a small freight railway station on the English network, with a decidedly poor maintenance condition. The rails contain defects in the rail heads in many places, i.e. split defects, both lateral and longitudinal [12]. This proves a high track load and negligence in maintenance works.

Fig. 4 shows the result of testing these tracks, carried out by the Plowman Craven company, with the Vogel R3D drone with 100 MPx optics, flying at a height of $25 \mathrm{~m}$ above the tracks [17], [19]. The individual photos in Figs. 4a to d are successive enlargements of the same part of the station along the tracks, together with the rolling stock. It is not difficult to notice that despite the supplemented ballast, the condition of the rails in many places practically prevents the normal movement of rail vehicles..

a)

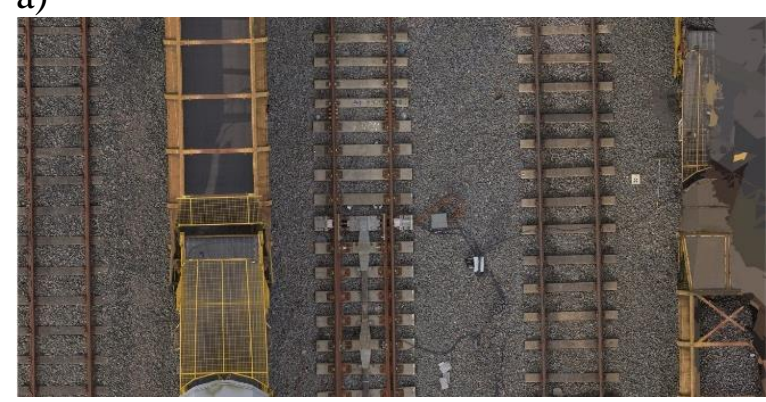

c)

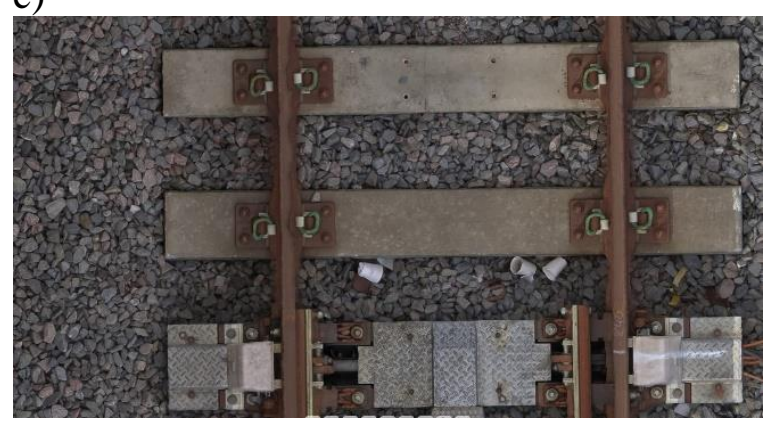

b)

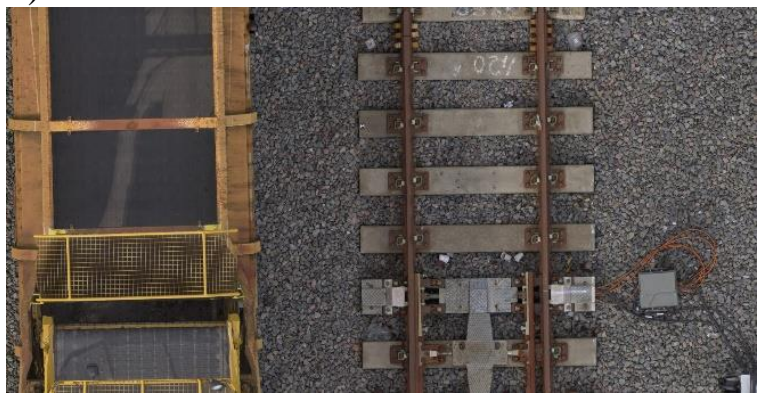

d)

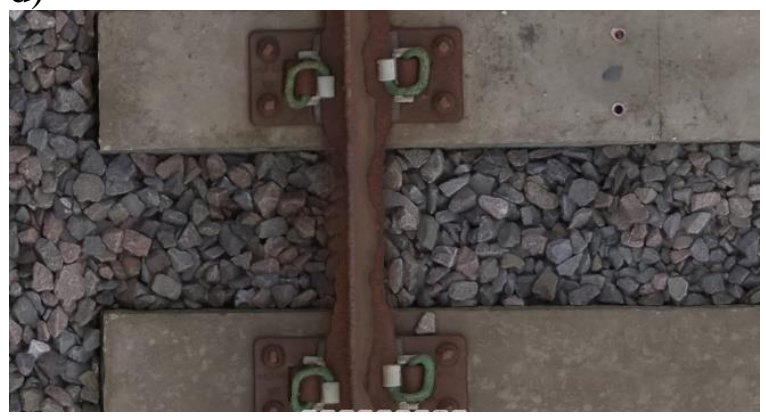

4. Visualization of station track tests with a drone: a) image of a track fragment with a turnout, b), c) and d) subsequent enlargements of the image of this part of the track with damaged rails [[17]]

In order to assess the significant damage that is not too sophisticated not to notice in the photos, the author used a fairly classic algorithm, especially useful for assessing the geometry of split defects.

After obtaining an image from the drone of the track fragment, the rails should be extracted, i.e. images of their running surfaces of the heads, Fig. 5. This is done in the process of narrowing the image down to a certain region of Interest - ROI, which has a decisive impact on the accuracy of further damage assessment. Here, gradient methods can be used to detect the edges of the rail head, methods based on first-order statistics examining the brightness intensity distribution determining the mean value, variance or entropy, as well as methods based on second-order statistics, the so-called Haralick measures, or based on multiple scales, using the Gauss or Laplacc pyramid and the wavelet transform, considered to be the most advanced [10], as in the example in Fig. $\mathbf{6 d}, \mathbf{g}$ and $\mathbf{j}$. and several characteristic track samples (rail + ballast) with dimensions of 400x400 pixels were selected from them, Fig.6a,b and c. 


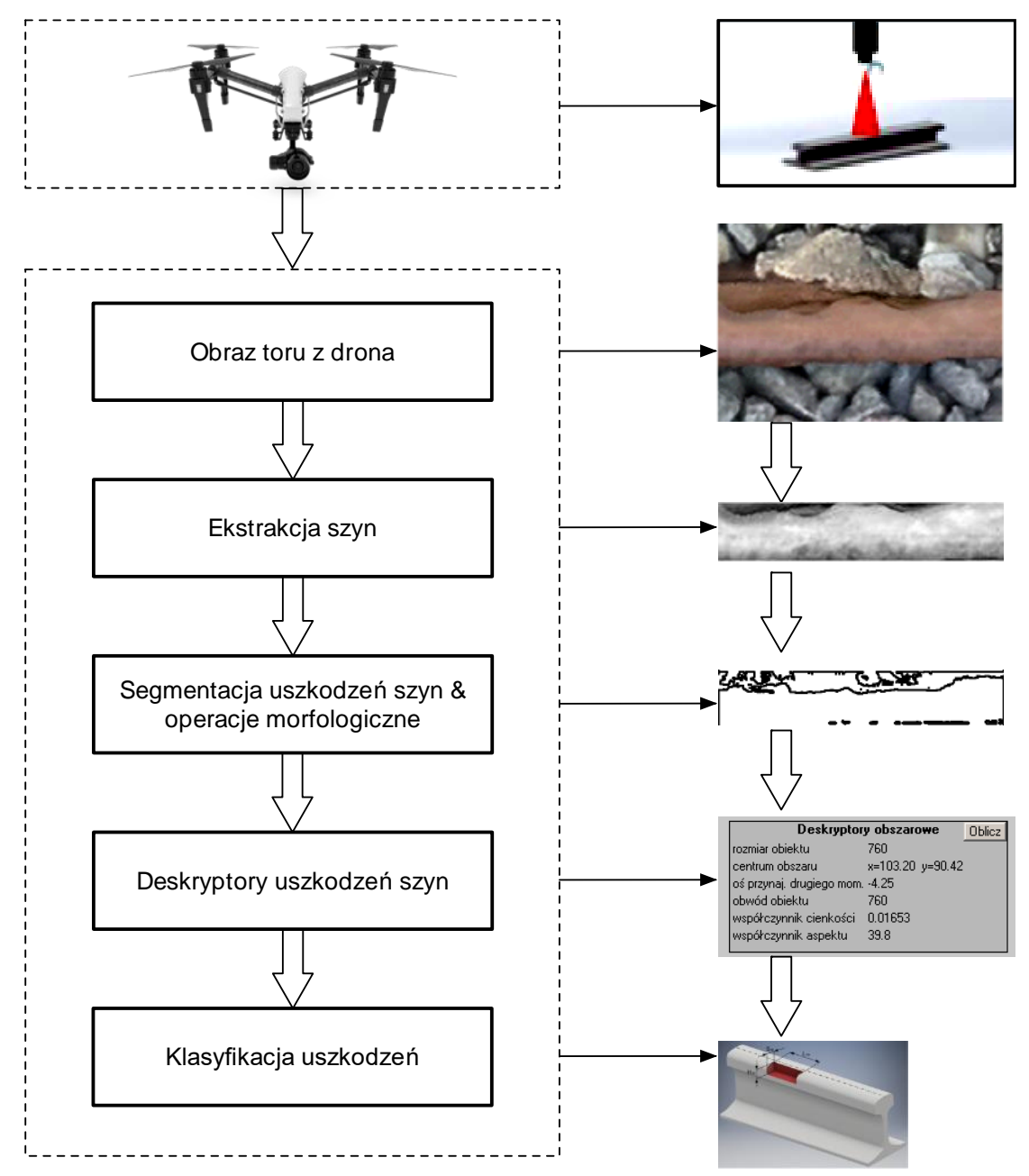

5. Algorithm for image processing of rail damage

In the sequence, threshold segmentation was applied, obtaining a binary image on which operations using morphological operations can already be performed. In the case of the conducted experiments, the author, after binarization with the threshold of 120 , used the remove function and dilatation, Fig. 6 , thanks to which the edges of damaged areas of split rails were determined, Fig. 6f, and, $\mathbf{l}$.

Now a defect analysis can be performed, which is another process following the initial image processing, the so-called pre-processing, where irrelevant or disturbing elements from the point of view of the intended purposes of the analysis have been eliminated.

A simple way leads here to measure the sought quantitative features of the analyzed images of defects. Here you can designate the so-called area descriptors of images of defects in rails, as defined in the author's work [10]. For the processed samples from Fig. 6f, i, l, descriptor values such as the size and circumference of the defect, the center of the defect area, the axis of at least the second moment, the thinness and the aspect coefficient were determined. The greatest damage to the rail in the form of a split defect is shown in the sample shown in Fig. 6a. It should also be noted a symbolic twist of the rail axis, of the order of several degrees for samples $6 \mathrm{~b}$ and $6 \mathrm{c}$, which does not affect the measurement result. Due to the similar shape of the rail, the values of the thinness and aspect coefficients do not differ much from one sample to another. 
a)

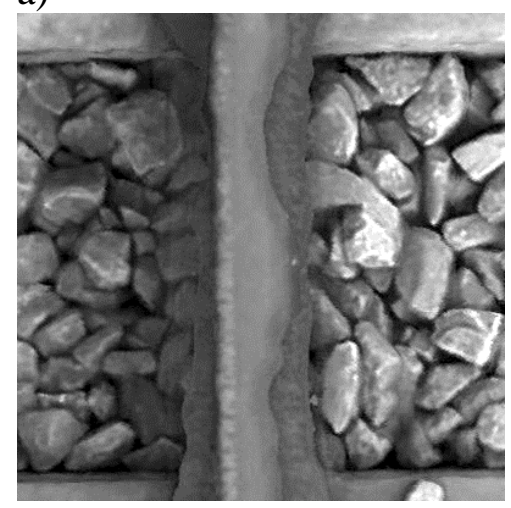

d)

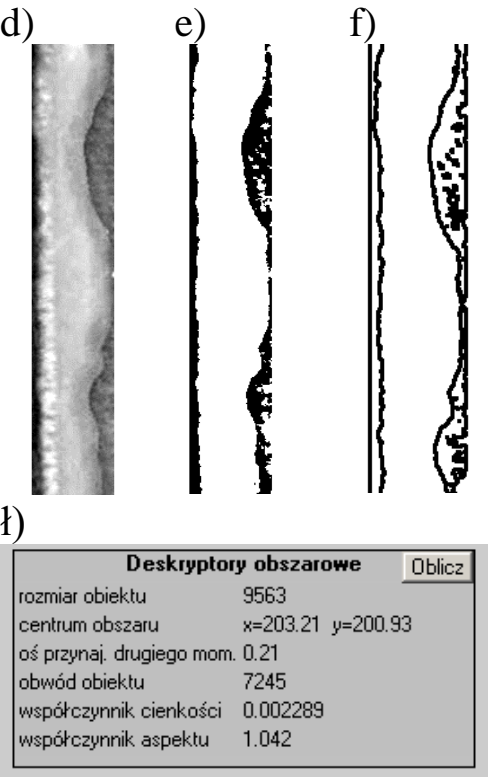

b)

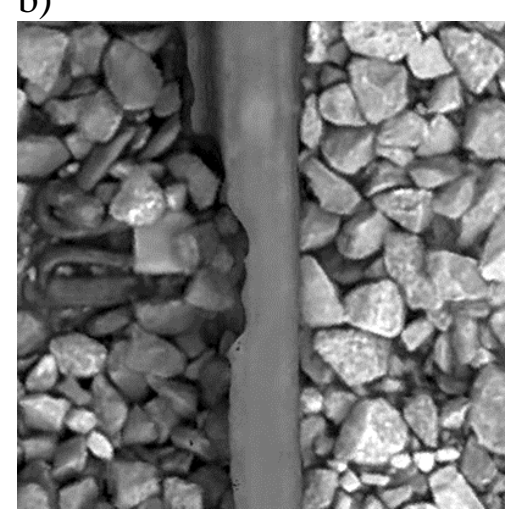

g)

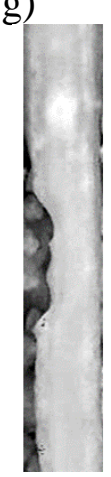

m)

h)

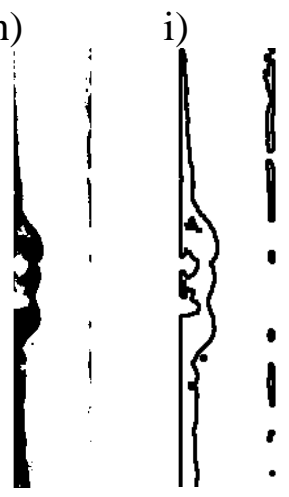

c)

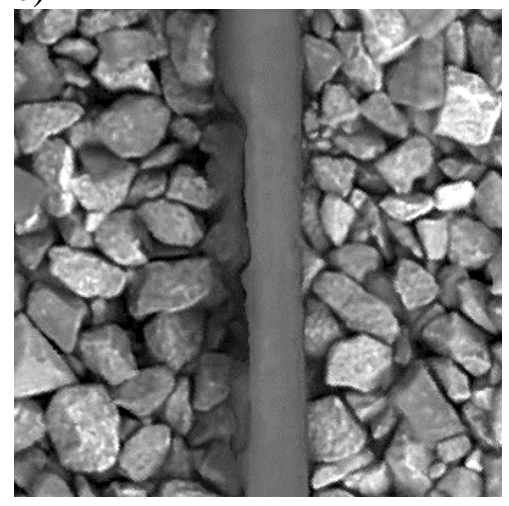

j)

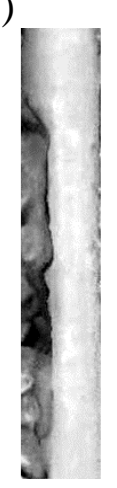

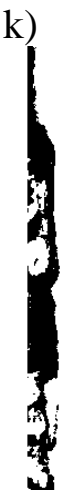

1)

n)

6. Preprocessing and area descriptors of images of damaged glass samples

With a significant amount of data obtained from tests, most often automated, one can implement data mining algorithms, helpful in the classification of images of defects in rails (only the matter of choosing a defect classifier), Fig. 5. Next, is the interpretation of the obtained results and taking appropriate classification decisions based on them. They are used for the diagnostic evaluation of the tested rails, e.g. on the basis of descriptor parameters, which is the ultimate goal of the analysis. These issues are the subject of separate considerations by the author [[11]].

\section{Advantages and disadvantages of testing the railway track drones}

The use of drones in railway surface research is gaining more and more supporters around the world, as evidenced by their following advantages:

- low cost of research compared to traditional inspection, e.g. with diagnostic vehicles and reduced employment (drones on the railroad are also called "workers"), and in the case of using autonomous drones equipped with artificial intelligence (AI) technologies, there will be a drastic reduction research personnel, cost, time and risk,

- test without introducing track occupancy or without any limitation of train traffic, especially in the case of a drone connected to the SRK system, because the inspection system would have coded information about the location "home", which will release the drone only after receiving a notification from the signaling system, 
about the track vacancy, and if the signaling system will report the approaching train, then the drone will be summoned to "home",

- research mobility, i.e. quick delivery of drones to the research site (by train - Fig. 3, by car),

- testing of tracks that are difficult to access, limited by high slopes, in tunnels, on bridges and viaducts..

Overall, inspecting rail infrastructure and assisting accident rescue operations are two key areas where rail companies can greatly benefit from the implementation of drone technology.

However, the use of drones over a railway line can be associated with significant hazards, risks and presents serious operational challenges, namely:

- short sections of the track are tested once because the flight time of the drone is 20 - 30 minutes and this may translate into problems with returning "home" in the event of any disruptions,

- there are some environmental threats to the Global Positioning System (GPS), such as bridges, viaducts, tall trees and the like that limit the view of the sky, in addition, Base Transceiver Stations (BTS) used in wireless communication systems, including GSM, equipped with electromagnetic wave antennas, usually on a high mast and the so-called solar storms, i.e. sudden and intense changes in the Earth's magnetic field,

- when testing in confined spaces (tunnels), strong airflows must be expected and must be taken into account,

- most drones do not tolerate physical collisions, so the risk of a collision should be properly managed to avoid damage to both drones and rail infrastructure,

- flight below the live traction line may cause interference with the compass onboard drones and the risk of collision with rolling stock,

- the risk of a collision when operating drones beyond the visual line of sight (BVLOS) is also increased, as camera failure or loss of video link forces the operator to visually inspect and maneuver, which can be difficult, and sometimes even impossible, in the thicket of railway facilities.

Therefore, global research centers, in cooperation with railway network managers, investigate the unique challenges related to the use of drones in operations for inspection and maintenance of railway infrastructure. This research involves gathering knowledge about the experiences and concerns of rail operators and others working in this environment. It is expected that the results of the research will help to formulate safety requirements for unmanned aerial vehicles on railway grounds and to analyze the applicable regulations and procedures regulating their use.

\section{Conclusions}

Growth forecasts for the drone market show enormous potential in terms of using their commercial opportunities also in the field of railway research and management.

It is also worth indicating the possibilities of implementation by PKP PLK S.A. drones for inspecting railway infrastructure. According to the author, the field of activity here is large, and the selected proposals are:

- electric traction, including inspection of the technical condition of steel structures (deformation, corrosion), traction cables as well as contact tests with a pantograph (within poles), thermal imaging tests of insulators (electrical leakage),

- railway viaducts and bridges of various structures (displacement dynamics), damage especially in hard-to-reach places, 
- railway track - inventory and acquisition of technical condition (sleepers, fastenings, rail joints), switches and turnouts (dynamics, geometry, heating thermovision), gauge (also in the tunnelh),

- sliding slopes and embankments, trees threatening the line, overgrowing vegetation (along with spraying),

- stations (buildings, control boxes, traffic stations), platforms (sheds), railway traffic control devices.

\section{Source materials}

[1] Banić M., Miltenović A., Pavlović M., Ćirić I.: Intelligent Machine Vision Based Railway Infrastructure Inspection and Monitoring Using UAV. Facta Universitatis, Series: Mechanical Engineering Vol. 17, No 3, 2019, s. 357 - 364.

[2] Both E.: Remote track inspections using drones. Infrastructure, 14 June 2019, https://infrastructuremagazine.com.au/2019/06/14/remote-track-inspections-usingdrones/, dostęp: 18.05.2020.

[3] Debevec R.: A Smart UAV Platform for Railroad Inspection. Electronic Theses and Dissertations. B.S. University of Central Florida, 2019, 54 s.

[4] Drone-based rail surveys are a 'game changer'. CIOB, 14 August 2017, http://www.constructionmanagermagazine.com/technology/drone-based-system-gamechanger-rail-surveying/, dostęp: 18.05.2020.

[5] Drony z termowizja chronia pociagi PKP Cargo przed kradzieżami. Rynek Kolejowy, 13 styczeń 2018, https://www.rynek-kolejowy.pl/mobile/drony-z-termowizja-chroniapociagi-pkp-cargo-przed-kradziezami-85224.html, dostęp: 18.05.2020.

[6] Flammini F., Naddei R., Pragliola C., Smarra G.: Railway Infrastructure Monitoring by Drones. International Conference on Electrical Systems for Aircraft, Railway, Ship Propulsion and Road Vehicles \& International Transportation Electrification Conference (ESARS-ITEC), November 2016, $6 \mathrm{~s}$.

[7] Garg P., Ozdagli A., Moreu F.: Railroad Bridge Inspections for Maintenance and Replacement Prioritization Using Unmanned Aerial Vehicles (UAVs) with Laser Scanning Capabilities. TRB's Rail Safety IDEA Program: Sponsoring Innovation to Improve Railroad Safety and Performance. Transportation Research Board Annual Conference, Washington D. C., January 2018, 29 s.

[8] Inspection and monitoring of railway infrastructure using aerial drones. ESCAP /TARN/WG/2019/4. 6th session Bangkok, 10 and 11 December 2019, $16 \mathrm{~s}$.

[9] Kochan A., Rutkowska P., Wójcik M.: Inspection of the Railway Infrastructure with the use of Unmanned Aerial Vehicles. Archives of Transport System Telematics, Vol.11, Issue 2, 2018, s. 11-17.

[10] Lesiak P., Bojarczak P.: Przetwarzanie $i$ analiza obrazów $w$ wybranych badaniach defektoskopowych. Monograficzna seria wydawnicza Biblioteka Problemów Eksploatacji, ITE-PIB Radom 2012.

[11] Lesiak P., Bojarczak P.: Algorytmy klasyfikacji obrazów wad w badaniach toru kolejowego. Monografia Wydziału Transportu i Informatyki WSEI w Lublinie pod red. T. Rymarczyka „Współczesne trendy technologiczne w informatycznych systemach złożonych”. Wyd. INNOVATIO PRESS, Lublin 2019, s. 41 -73.

[12] Lesiak P., Podsiadło R.: Modelowanie numeryczne geometrii wzorców wad powierzchniowych szyn kolejowych. Przegląd Komunikacyjny, Tom: LXXIV, Zeszyt 6/2019, s. 14-18,

[13] Lesiak P.: Inspekcja i utrzymanie infrastruktury kolejowej z wykorzystaniem dronów. Inspection and maintenance of railway infrastructure with the use of Unmanned Aerial Vehicles. Problemy Kolejnictwa. Zeszyt 188 (w druku). 
[14] Moreu F., Taha M.R.: Railroad Bridge Inspections for Maintenance and Replacement Prioritization Using Unmanned Aerial Vehicles (UAVs) with Laser Scanning Capabilities. IDEA Program Final Report. Contract Number Rail Safety 32. University of New Mexico, 2016 - 2018, $29 \mathrm{~s}$.

[15] Project EREVOS. European Union's Horizon 2020 research and innovation programme under grant agreement No 780265. ESMERA, 2018, http://www.esmeraproject.eu/erevos/, dostęp: 18.05.2020.

[16] Rau J.Y., Hsiao K.W., Jhan J.P., Wang S.H., Fang W.C., Wang J.L.: Bridge Crack Detection Using Multi-Rotary UAV and Object-Base Image Analysis. The International Archives of the Photogrammetry, Remote Sensing and Spatial Information Sciences, Vol. XLII-2/W6, 2017. International Conference on Unmanned Aerial Vehicles in Geomatics, 4-7 September 2017, Bonn, Germany, s. 311-318.

[17] Rail

Surveys.

Plowman

Craven. https://plowmancraven.s3.amazonaws.com/panoramics/grange-sidings/index.html dostęp: 18.05.2020.

[18] Ravitharan R.: The Implementation of Unmanned Autonomous Systems for Railway Inspection. Monash University, Australia. Institute of Railway Technology, https://www.unescap.org/sites/default/files/Item6_Monash_UAS_0.pdf, dostęp: 18.02.2020.

[19] Right on track. AECMagazin 24 January 2018. https://aecmag.com/technologymainmenu-35/1520-right-on-track-drone-surveying-plowman-craven , dostęp: 18.05.2020.

[20] Singh A. K., Swarup A., Agarwal A. , Singh D.: Vision based rail track extraction and monitoring through drone imagery. ICT Express 5, 2019, s. 250 - 255.

[21] Smith, E.M.: A collection of computer vision algorithms capable of detecting linear infrastructure for the purpose of UAV control. MSc Thesis, Virginia Tech, USA, 2016, $101 \mathrm{~s}$.

[22] Sherrock E., Neubecker K.: Unmanned Aircraft System Applications in International Railroads. U.S. Department of Transportation. Federal Railroad Administration. Office of Research, Development and Technology Washington, DC 20590, February 2018, 35 s.

[23] Wu Y., Qin Y., Wang Z., Jia L.: A UAV-Based Visual Inspection Method for Rail Surface Defects. Applied Sciences, Vol. 8, No. 7, 1028, 2018, 20 s.

[24] Wójcik M.: Badanie stanu technicznego infrastruktury kolejowej $z$ wykorzystaniem bezzałogowych statków powietrznych. Ogólnopolska Konferencja Naukowo - Techniczna, Transport Kolejowy 2017, Przeszłość - Teraźniejszość - Przyszłość, UTK, s. 148 - 164.

[25] Visual Intelligence. https://visualintelligenceinc.com/rail-2/ , dostęp: 18.05.2020.

[26] Zhang D., Vong Ch.H., Ravitharan R., Reichl P., Chung H.: Unmanned Aerial System (UAS) for Railway Inspection. AusRAIL 2018, Rail for a Better Future, 27-28 November 2018, Canberra, ACT, 2018, 9 s. 